\title{
Short Communication: Effect of different feed combination on the growth development of spotted cuscus (Spilocuscus maculatus) in captivity
}

\author{
MARTHA KAYADOE ${ }^{1, \boldsymbol{\eta}}$, ANA ROCHANA ${ }^{2}$, UJANG HIDAYAT TANUWIRIA ${ }^{2}$, SAULAND SINAGA ${ }^{2}$ \\ ${ }^{1}$ Faculty of Animal Husbandry, Universitas Papua. Jl. Gunung Salju, Amban. Manokwari 98314. West Papua, Indonesia. \\ Tel.: +62-986-211430; Fax.: +62-986-211430. "email: marthakayadoe837@ gmail.com \\ ${ }^{2}$ Faculty of Animal Husbandry, Universitas Padjajaran. Jl. Raya Bandung-Sumedang Km 21, Jatinangor, Sumedang 45363, West Java, Indonesia
}

Manuscript received: 4 September 2018. Revision accepted: 29 January 2019.

\begin{abstract}
Kayadoe M, Rochana A, Tanuwiria AH, Sinaga S. 2019. Short Communication: Effect of different feed combination on the growth development of spotted cuscus (Spilocuscus maculatus) in captivity. Biodiversitas 20: 526-531. One of the problems in maintaining cuscus in captivity was feed factor. Farmers had given various combinations of feed for cuscus, and several studies had been conducted on cuscus feed. For cuscus feed, it mostly used more than two types of feed, and the most dominant was banana. Inefficiency occurred fresh feed was prepared with more than two types. It can be costly, time-consuming and has more digestibility problem. Therefore, it was necessary to conduct an assessment by limiting the number of feed in two types to see the benefits of the ration (70\% carbohydrate feed sources Musa paradisiaca var. mas and 30\% from Pometia pinnata leaves, Pongamia pinnata leaves, Ipomoea aquatica, Brassica rapa var. parachinensis and Gryllus spp. The research was conducted for 36 days consisting of 2 periods, namely the adaptation period ( 5 days) and the data collection period ( 7 days), 3 times replications. The amount of feeding was limited based on $90 \%$ of adequacy of dry matter (preliminary research). The weighting of the initial body weight of cuscus and the final weight was carried out at the beginning and end of the period of data collection. Faecal was collected every day during the period of data collection. Each type of feed and fecal was analyzed for the dry matter. The results showed no significant effect $(\mathrm{P}>0.01)$ on dry matter consumption, but significantly affected the digestibility coefficients of dry matter. The preferred ration was $100 \%$ M. paradisiaca var. mas, which $49.99 \mathrm{~g} /$ day, then a combination of M. paradisiaca var. mas with $I$. aquatica $48.187 \mathrm{~g} / \mathrm{day}$ and M. paradisiaca var. mas combination with Averrhoa carambola (48.06 g/day), while the less preferred combination was M. paradisiaca var. mas with leaves from forest plants and combination of M. paradisiaca var. mas and animal protein feed sources i.e. Gryllus spp. However, the highest digestibility coefficient was achieved in $100 \%$ M. paradisiaca var. mas and M. paradisiaca var. mas combine with Gryllus spp. Furthermore, the relationship between digestibility coefficient and body weight gain showed that the combination of $M$. paradisiaca var. mas and Gryllus spp. had higher body weight gain compared to $100 \%$ Musa paradisiacal var. mas. Based on this study it was concluded that cuscus required a combination of carbohydrate feed sources and animal protein feed sources obtained from M. paradisiaca var. mas and Glyllus spp.
\end{abstract}

Keywords: Cuscus, various combination of feed, captivity

\section{INTRODUCTION}

Cuscus is one of the endemic species in Papua, Indonesia. Currently, two genera of cuscus have been identified, i.e. Spilocuscus spp. and Phalanger spp. Spotted cuscus (Spilocuscus maculatus) are more commonly in the Biak Nature Reserve (Dahrudin et al. 2005; Pattiselanno and Koibur 2008), in the North Coast Area of Manokwari (Fatem and Sawen 2007; Nakoh et al. 2010) and also areas around the Cenderawasih Bay (Pattiselanno 2007; Saragih et al. 2010). Their existence in the nature reserve areas is strongly supported by the availability and biodiversity of flora, such as fruits and leaves that can be used as sources of food (Saragih et al. 2010; Sinery et al. 2013, 2014). However, the conversion of forest area is presently increasing along with the development of infrastructure and other facilities. This significantly contributes to the declining area of natural reserve area from 1,743,108 ha in 2013 to 452,954 ha in 2014 (BPS 2015). Therefore, it also has effect on the habitat of particular wildlife species, with strongly rely on the forest canopy like cuscus.
The number of living habitat of cuscus and its food sources plummeted, so that a solution to overcome this problem is needed. The maintenance of cuscus in captivity can be an alternative, but the factors for providing feed need to be considered. Providing the appropriate diets is one of the important factors determining cuscus survival in captivity. According to the information from the locals in Manokwari, rearing cuscus in captive environment is quite difficult because these animals are not able to survive longer in captivity. Most of the cuscus survived less than one month. The most problems are providing the appropriate diet mimicking natural foods consumption in their natural habitat. Musa paradisiaca var. mas (bananas) are the most popular food selected the locals, because $M$. paradisiaca var. mas are easy to find in the local markets. In addition, cuscus prefers better to consume this fruit than other fruits (Farida et al. 2004; Saragih et al. 2010). However, in their wild environment, cuscus typically consumes a balanced amount of fruit, leaves, and insects (Kartikasari et al.2013). This might be because they need to balance their nutritional needs based on their consumption 
needs. Therefore, the formulation of the appropriate diet menu by considering the dietary habits of cuscus in the wild nature as well as the need of their essential nutrients is the best approaches to conserve the cuscus in captivity.

The basic need for nutrients can be fulfilled by combining various type of feed ingredients. The combination of basal feed and other feed ingredients for additional source of food would support adequate nutrients for animals. Kayadoe et al. (2015) reported that $M$. paradisiaca var. mas is the most preferred type of food compared to other types of fruits. In addition, Farida et al. (2004) and Saragih et al. (2010) also reported that in captivity, cuscus was generally fed by Musa paradisiaca. Therefore, $M$. paradisiaca var. mas could be selected as the basal feed ingredients.

The banana with various types of leaves, fruits, and insect can also the balance food of diets. Insects are the natural feed ingredients consumed by cuscus in wild environment (Kartikasari et al. 2013). Many types of research regarding the use of animal protein for feeding cuscus in captivity has been reported: Saragih et al. (2010) utilized fish for cuscus captivate in Retewi Island, Province of Papua; whereas Hume et al. (1997) used eggs for captivating cuscus in Papua New Guinea. In addition, Sinaga et al. (2010) utilized Gryllus spp. (crickets) in their research as a source of protein for coucang (Nycticebus coucang).

Food consumed by animal will be digested to support their body growth and, eventually, would maintain their body weight. Generally, animal's diet has a high vegetable protein, even though it provides adequate protein for body, but it has a lower rate of digestion (Bailey 1984). Furthermore, protein sources from animal origin have a lower level of palatability due to the aroma of the food (Sutardi 1980). Sensory organs affect the selection habit in selecting diets before they are consumed by an animal (Kartadisastra 1997). The present research focuses on finding an appropriate formulating diet for cuscus which has a high rate of digestibility as implied by their bodyweight gain.

\section{MATERIALS AND METHODS}

\section{Study area}

Research was conducted in the Livestock Laboratory, Faculty of Animal Science, University of Papua, Manokwari, West Papua, Indonesia. Seven of the spotted cuscus were used in this study with a body weight ranging from $1.689 \pm 0.636 \mathrm{~kg}$. The cuscus has been adapted in the environment for five months. Each of them was placed in an individual cage of $75 \mathrm{~cm} \mathrm{x} 45 \mathrm{~cm} \mathrm{x} 45 \mathrm{~cm}$. One feeder and one drink tube were placed in each individual cage. Research was conducted between October and November 2017, within 36 days of observation separated into three periods. Each period consisted of 12 days; 5-first-days was used for the adaptation of the diets, and the last 7 days was used for measuring the variables in the study.

\section{Diet formulation}

Diets in the present research utilized banana ( $M$. paradisiaca var. mas) as the basal feed; whereas starfruits (A. carambola), crickets (Gryllus spp.), and several types of leaves and vegetables, such as water spinach (Ipomoea aquatica), green mustards (Brassica rapa var. parachinensis), matoa leaves (Pometia pinnata), Pongamia pinnata leaves as the additional feed. The combination of diet was a mixture of $70 \%$ basal feed (bananas) and $30 \%$ additional feed. Each of the additional feed was going through a drying process $\left(60^{\circ} \mathrm{C}\right.$ for 72 hours $)$ before the diets are mixed. The amount of mixed diet given in each day was $50 \mathrm{~g}$ dry matter/day. There are seven different combinations of diets in this study (Table 1). During seven days in collecting period, diets were weighted before being given. The daily bodyweight of cuscus was also measured before and after each collecting period. The fecal collection was carried out every morning before the next-day-diet was given and the fresh fecal was weighed. The fecal samples were then analyzed using dry matter analysis.

\section{Data analysis}

Data were analyzed using analysis of variance (ANOVA) and continued with a follow-up test (Honestly Significant Difference) to determine the best type of treatment (Sastrosupadi 1999).

\section{RESULTS AND DISCUSSION}

\section{Nutrient content}

Nutrient content of seven types of feed for cuscus in the study was presented in Table 2 . The results of the analysis of 7 feed ingredients obtained from the dry matter content of basal feed (M. paradisiaca var. mas) was $27.56 \%$ (as fed), while additional feed in the ranging was 89.32$97.55 \%$ (as $100 \%$ dry matter). Crude fiber content higher in leaves from forest plants, while the highest crude fat and gross energy in crickets.

Table 1. Combination of diet treatment of cuscus

\begin{tabular}{|c|c|c|}
\hline \multirow{2}{*}{ Treatment } & \multicolumn{2}{|c|}{ Combination of diet $(100 \%$ dry matter) } \\
\hline & Basal feed & Additional feed \\
\hline A & Musa paradisiaca var. mas (100\%) & - \\
\hline B & M. paradisiaca var. mas $(70 \%)$ & + Averhoa carambola $(30 \%)$ \\
\hline $\mathrm{C}$ & M. paradisiaca var. mas $(70 \%)$ & + Brassica rapa var parachinensis $(30 \%)$ \\
\hline $\mathrm{D}$ & M. paradisiaca var. mas $(70 \%)$ & + Ipomoea aquatica $(30 \%)$ \\
\hline $\mathrm{E}$ & M. paradisiaca var. mas $(70 \%)$ & + Pometia pinnata leaves (30\%) \\
\hline $\mathrm{F}$ & M. paradisiaca var. mas (70\%) & + Pongamia pinnata leaves (30\%) \\
\hline G & M. paradisiaca var. mas ( $70 \%)$ & + Gryllus spp. $(30 \%)$ \\
\hline
\end{tabular}


Table 2. Composition of nutrient of seven types of feed of spotted cuscus in captivity

\begin{tabular}{|c|c|c|c|c|}
\hline \multirow[b]{2}{*}{ Types of feed } & \multicolumn{4}{|c|}{ Nutrient composition of feed } \\
\hline & $\begin{array}{l}\text { DM } \\
(\%)\end{array}$ & $\begin{array}{c}\text { Crude } \\
\text { fiber }(\%)\end{array}$ & $\begin{array}{l}\text { Crude } \\
\text { fat }(\%)\end{array}$ & $\begin{array}{c}\mathbf{G E} \\
(\mathrm{kcal} / \mathrm{kg})\end{array}$ \\
\hline \multicolumn{5}{|l|}{ Basal feed } \\
\hline $\begin{array}{l}\text { Musa paradisiaca var. } \\
\text { mas }\end{array}$ & 27.56 & 4.35 & 1.13 & 3629.00 \\
\hline \multicolumn{5}{|l|}{ Additional feed } \\
\hline Averhoa carambola & 97.55 & 13.96 & 2.67 & 3215.65 \\
\hline $\begin{array}{l}\text { Brassica rapa var. } \\
\text { parachinensis }\end{array}$ & 94.73 & 13.95 & 1.21 & 2879.95 \\
\hline Ipomoea aquatica & 94.69 & 13.78 & 1.62 & 3648.85 \\
\hline Pometia pinnata leaves & 96.77 & 20.75 & 2.92 & 2803.29 \\
\hline $\begin{array}{l}\text { Pongamia pinnata } \\
\text { leaves }\end{array}$ & 95.65 & 18.66 & 2.76 & 3248.66 \\
\hline Gryllus spp. & 89.32 & 6.95 & 22.83 & 5340.59 \\
\hline
\end{tabular}

Note: DM: dry matter, GE: gross energy

Table 3. Composition of the combination diet in each treatment

\begin{tabular}{lccc}
\hline \multirow{2}{*}{ Treatment } & \multicolumn{3}{c}{ Composition of feed } \\
\cline { 2 - 3 } & \multicolumn{2}{c}{ g/feed } & $\begin{array}{c}\text { g dry matter/ } \\
\text { treatment }\end{array}$ \\
\cline { 2 - 3 } & Basal feed & Additional feed & \\
A & & & 50 \\
B & 181.42 & - & 50 \\
C & 126.99 & 15.37 & 50 \\
D & 126.99 & 15.83 & 50 \\
E & 126.99 & 15.84 & 50 \\
F & 126.99 & 15.50 & 50 \\
G & 126.99 & 15.68 & 50 \\
& 126.99 & 16.79 & \\
\hline
\end{tabular}

\section{Composition of combination diet in treatment ration}

Composition of basal and additional feed in each treatment showed in Table 3. The composition of the combination ration given in the conversion of the weight of dry matter was 50 grams (treatment A, B, C, D, E, F, and G). Each treatment consist of basal feed was 126.99 grams and additional feed in ranging were 15.37-16.79 grams, while in treatment A was only given 181 grams of basal feed.

\section{Consumption of the variety of mixed diets in gram dry matters (g DM)}

The combination feed would provide adequate nutrition for animals, because they can improve the ability to absorb essential vitamins and nutrients. Thus, it would eventually affect their production (Parakkasi, 1999). In addition, combination feed would improve the palatability of cuscus toward the diet in captivity. The goal of providing adequate nutrient factors for wild animals is to maintain their normal body weight and to attain normal growth rates for young animals (Roosendaal 2014).

The results of the amount of seven mixed diets consumed by spotted cuscus were presented in Table 4 . According to Table 4, there were no significant differences on each of consumed diet combinations $(\mathrm{P}>0.05)$, with the range of $45.773-49.999 \mathrm{~g} \mathrm{DM} /$ tail/day. This was presumably because the aroma of $M$. paradisiaca var. mas in the diet drove cuscus to like it. The mixed combinations of basal feed $(70 \%)$ and additional feed $(30 \%)$ offers no chance for cuscuses to separate them, so that they consumed it all. Based on the type of additional feed the higher amount of feed consumed by cuscus was diet A (49.999 g DM/tail/day). Crude fiber content in Pometia pinnata leaves was higher more than another feed, so that consumption ration in treatment $\mathrm{E}$ was lower. The high crude fat content in crickets causes treatment $G$ to also slightly lower consumed by cuscus. Fiber and fat levels to affect cuscus taste to consume combination ration in treatment E and G. This was accordance with Sutardi opinion (1980) that the appetite of an animal including wildlife is also influenced by taste.

When compared between spotted cuscus in this study and bear cuscus (Farida.et al. 2004), it turns out the consumption dry matter level of spotted cuscus (45.773$49.999 \mathrm{~g} \mathrm{DM})$ is lower than bear cuscus $(89.28 \pm 31.28 \mathrm{~g}$ DM/tail/day). Previous study by Farida et al. (2004) composed different types of food, such as plant-based food and dog food, while in the research on spotted cuscus utilized provides crickets (Gryllus spp.) as animal protein source. The range of food intake (predicted DM intake as a percentage of body weight) of a spotted cuscus in the present study is $2.71 \%-2.96 \%$ of body weight namely range of consumption of ration per day (45.773-49.999) divided by the initial body weight of cuscus, while bear cuscus was $1.5-3 \%$ (Farida et al. 2004) and soil cuscus, which is $2.12 \%$ (Hume et al. 1997).

Table 4. Averages of seven different mixed diets consumed by spotted cuscus (g dry matter/tail/day)

\begin{tabular}{llc}
\hline Code & \multicolumn{1}{c}{ Treatment } & $\begin{array}{c}\text { Consumption } \\
\text { (g dry matter/day) }\end{array}$ \\
\hline A & Musa paradisiaca var. mas 100\% & 49.999 \\
B & M. paradisiaca var. mas 70\% + Averhoa carambola 30\% & 48.060 \\
C & M. paradisiaca var. mas 70\% + B. rapa var parachinensis 30\% & $46.957 \pm 2.93$ \\
D & M. paradisiaca var. mas 70\% + Ipomoea aquatica 30\% & 48.187 \\
E & M. paradisiaca var. mas 70\% + Pometia pinnata leaves 30\% & $45.773 \pm 2.94$ \\
F & M. paradisiaca var. mas 70\% + Pongamia pinnata leaves 30\% & $46.411 \pm 0.71$ \\
G & M. paradisiaca var. mas 70\% + Gryllus spp. 30\% & $46.249 \pm 4.74$ \\
\hline N
\end{tabular}

Note: DM: dry matter; GE: gross energy 
Table 5. Digestibility coefficiency for seven mixed diets measured in captive spotted cuscus and its relationship with body weight gain

\begin{tabular}{|c|c|c|c|}
\hline Code & Treatment & $\begin{array}{c}\text { Digestibility } \\
\text { coefficient }(\%)\end{array}$ & $\begin{array}{l}\text { Body weight } \\
\text { gain (g/day) }\end{array}$ \\
\hline A & M. paradisiaca $100 \%$ & $96.83^{\mathrm{b}} \pm 0.62$ & 13.95 \\
\hline $\mathrm{B}$ & M. paradisiaca $70 \%+$ A.carambola $30 \%$ & $89.097^{\mathrm{a}} \pm 3.13$ & 6.20 \\
\hline $\mathrm{C}$ & M. paradisiaca $70 \%+$ B.rapa var parachinensis $30 \%$ & $90.196^{\mathrm{a}} \pm 1.02$ & 3.43 \\
\hline $\mathrm{D}$ & M. paradisiaca $70 \%$ + Ipomoea aquatica $30 \%$ & $87.11^{\mathrm{a}} \pm 2.39$ & 13.43 \\
\hline $\mathrm{E}$ & M. paradisiaca $70 \%+$ Pometia pinnata leaves $30 \%$ & $87.02^{\mathrm{a}} \pm 1.65$ & 0.30 \\
\hline $\mathrm{F}$ & M. paradisiaca $70 \%+$ Pongamia pinnata leaves $30 \%$ & $87.94^{\mathrm{a}} \pm 3.77$ & 2.76 \\
\hline $\mathrm{G}$ & M. paradisiaca $70 \%+$ Gryllus spp. $30 \%$ & $93.527^{\mathrm{b}} \pm 1.94$ & 18.57 \\
\hline
\end{tabular}

\section{Digestibility coefficiency}

Digestibility coefficient of mixed diet on spotted cuscus was presented in Table 5. Digestibility coefficients for diet A $(96.85 \%)$ and $\operatorname{diet} G(93.53 \%)$ were significantly different $(\mathrm{P}<01)$ compared to other diet combination treatments. This might be because the additional feed in diet $\mathrm{A}$ and diet $\mathrm{G}$, i.e. bananas and crickets are classified as low fibrous feed, so they are easily digested. In this research, it is reported that $M$. paradisiaca var. mas (bananas) and Gryllus spp (crickets) had lower fiber content, i.e., $4.35 \%$ and $6.95 \%$ respectively (Table 1). These findings were in accordance with previous studies mentioning that $M$. paradisiaca var. mas and crickets consisted of $4.53 \%$ crude fiber (Kayadoe et al. 2014 ${ }^{\mathrm{a}}$ ) and $7.30 \%$ crude fiber (Farida et al. 2008) respectively.

Another additional feed in diet combination treatments, on the other hand, had higher crude fiber content. The range crude fiber content in I. aquatica, Brassica rapa var parachinensis, Pometia pinnata leaves, Pongamia pinnata leaves and A. carambola range between $13.78 \%$ and $20.75 \%$ (Table 2). Previous research also reported a similar percentage of $11.67 \%$ and $35.55 \%$ (Kayadoe et al. 2014 ${ }^{\mathrm{a}}$ ). The high fiber content in diets causes ineffective digestion of foods.

\section{The relationship between digestion coefficients and body weight gain}

The relationship between digestion coefficients and bodyweight gain on spotted cuscus treated with mixed diets was presented in Table 5. This table shows that there was a relationship between digestibility coefficiency and body weight gain. Cuscus treated with diet A (M. paradisiaca var. mas $100 \%)$ and diet G (M. paradisiaca var. mas $70 \%+$ Gryllus spp. 30\%) not only had the second highest digestion coefficiency, but also had the second highest body weight gain. In addition, diet $G$ has a higher body weight gain than diet $\mathrm{A}$. This result demonstrates that cuscus requires animal-based protein to increase its body weight. The protein content of Gryllus spp. was $59.79 \%$ or $60.74 \%$ (Farida et al. 2008) or $48.84 \%$ (Sinaga et al. 2010). The high protein content in Gryllus spp. provides the protein required by spotted cuscus.

Even though Pongamia pinnata leaves are less preferred food cuscus, according to Chopade et al. (2008), these leaves have benefits like antioxidants and antidiarrhea. The vitamin E content, as a source of antioxidants, in the Pongamia pinnata leaves was about $30.566 \mathrm{mg} / 100 \mathrm{~g}$. This was higher than other types of leaves naturally consumed by cuscus in the wild, such as Pometia pinnata, B. rapa, and I. aquatica (Kayadoe et al. 2014 ${ }^{\mathrm{b}}$ ).

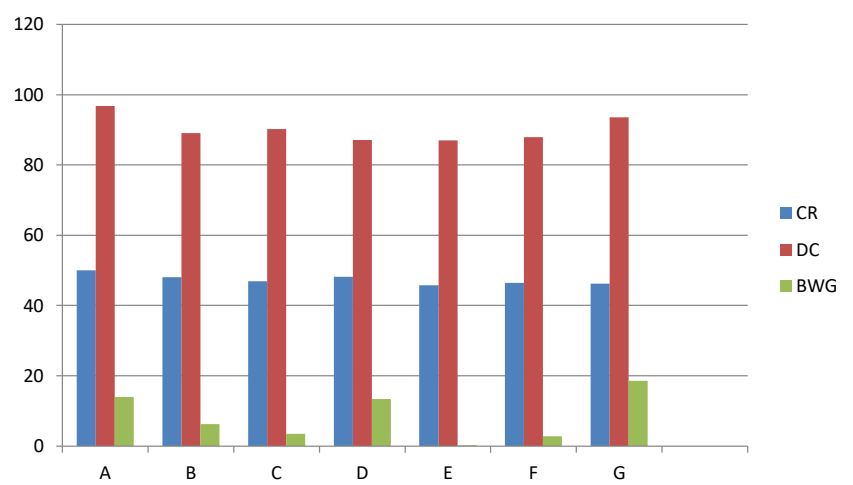

Figure 1. The relationship between feed consumption (CR), digestion coefficient (DC) and body weight gain (BWG)

\section{The relationship between food intake, digestion coefficients and body weight gain}

The relationship between food intake, digestion coefficients and bodyweight gain in spotted cuscus treated with 7 types of mixed diets was shown in Figure 1. Figure 1 shows that diet menu contained Gryllus spp. plays an important role in increasing the cuscus body weight gain(BWG). The amount of basal feed given is $70 \%$ and additional feed of $30 \%$ (dry matter) from crickets. It supported the need of protein from crickets for the development of cuscus, so that body weight gain of cuscus $33.12 \%$ better than the treatment given $M$. paradisiaca var. mas $100 \%$. This is corresponding with the opinion Pond et al. (1995) who reported that a balanced diet would help to achieve and maintain body weight gain. According to Table 2, protein intake from Musa paradisiacal var. mas was low $(6.46 \%)$. Therefore, a combination diet with crickets would supply the adequate protein that contributes to the cuscus weight gain.

Figure 1 also shows that the level palatability, as implied by the amount of feed consumed, tends to be the same with the average of $40-50 \mathrm{~g} \mathrm{DM} /$ tail/day. This is because the high concentration of banana (70-100\%) dominates the overall aroma of the mixed diet, so that cuscus tended to consume the same amount of diets. Ensminger et al. (1987) stated that non-ruminants are able to choose food based on the texture and taste as well as the nutritional content and the attractiveness of the color. This study shows that spotted cuscus had a higher body weight than other nocturnal animals. The averages of cuscus body weight were $1.689 \pm 0.636 \mathrm{~kg}$, whereas other animals such 
as coucang had adult weights ranges between $0.3-0.350 \mathrm{~kg}$ (Suprijatna and Wahyono 2000) and 0.3-0.4 kg (Payne et al. 2000). According to Imran et al. (2012), bodyweight can be used as a standard to measure the amount of a given diet. Data shown by Figure 1 demonstrates that cuscuses treated with mixed diet containing forest leaves had lower body weight gain than those given vegetable diets, Pometia pinnata and Pongamia pinnata leaves, had a higher content of crude fiber than vegetables (Table 2). This present study shows that the high crude fiber content in the mixed diet had a low impact on body weight gain. This was related to the report of the food-producing animals; high crude fiber content in food-producing animals' diet had a low impact on the body weight gain.

Based on this study, it can be concluded that the spotted cuscus treated with a combination ration (basal and additional feed) showed that the consumption of dry matter was not significant, however, there is a statistically significant difference in regards to digestibility coefficient of dry matter. Regarding the relationship between the digestibility coefficient of dry matter and body weight gain, the food combination of $70 \% \mathrm{M}$. paradisiaca var. mas with $30 \%$ Gryllus spp. Treated to cuscus had $93.53 \%$ digestibility coefficient of dry matter, which contributes to the body weight gain as much as $18.57 \mathrm{~g} /$ day. Feed combination is required for spotted cuscus in captivity. The need for essential nutrients for spotted cuscus can be fulfilled through food combination, especially combinations between carbohydrate and animal-based protein sources.

\section{ACKNOWLEDGEMENTS}

We would like to show our gratitude to the leaders of the University of Papua and the Dean of Faculty of Animal Science, University of Papua for providing facilities during this research. We would also like to thank the technicians of the Livestock Nutrition and Animal Feed Laboratory, Faculty of Animal Science, University of Padjadjaran in Jatinangor, Bandung as well as The Indonesian Livestock Research Center in Ciawi, Bogor for the hospitality in analyzing the samples of this study. This research is fully funded by the Graduate Scholarship from The Indonesian Ministry of Research, Technology, and Higher Education.

\section{REFERENCES}

Anggorodi R. 1995. Ilmu Makanan Ternak Umum. PT Gramedia. Jakarta. [Indonesian]

Bailey JA. 1984. Principle of Wildlife Management. John Willey and Sons. Canada.

BPS. 2015. Luas Kawasan Hutan dan Perairan Menurut Kabupaten/Kota 2010-2014.https://papuabarat.bps.go.id/staticable/2015/03/18/116. [Indonesian]

Chopade VV, Tankar AN, Pande VV, Tekade AR, Gowekar NM, Bhandari SR, Khandake SN. 2008. Pongamia pinnata: Phytochemical constituents, traditional uses and pharmacological properties: A review. Intl J Green Pharma 2 (2): 72-75.

Dahrudin H, Farida WR, Rohman AS. 2005. Plants Species as Feed Sources and Nesting Site of Cuscus (Family Phalangeridae) in Northern Biak Nature Reserve, Papua. Biodiversitas 6 (4): 253-258.

Ensminger ME, Olentine CG Jr. 1987. Feed and Nutrition Complete. 1st ed. Ensminger Publishing Company, California.

Farida WR, Wardani KK, Tjakradidjaja AS, Diapari D. 2008. Konsumsi dan penggunaanpakan pada tarsius (Tarsius bacanus) Betina di Penangkaran. Biodiversitas 9 (2): 148-151. [Indonesian]

Farida WR, Nurjaeni, Mutia R, Diapari D. 2004. Digestibility capacity of baptive bear cuscus (Ailurops ursinus) fed on alternative feed. BioSMART 6 (1): 65-70.

Fatem S, Sawen D. 2007. Jenis kuskus di Pantai Utara Manokwari Papua. Biodiversitas 8 (3): 233-237. [Indonesian]

Hume ID, Runcie MJ, Caton JM. 1997. Digestive physiology of the ground cuscus (Phalanger gymnotis), a New Guinean Phalangeridae marsupial. Australian J Zool 45: 561-571.

Imran, Budi S.P.S, Ngadiyono N, Dahlanuddin. 2012. Pertumbuhan pedet sapi bali lepas sapih yang diberi rumput lapang dan disuplemtasi daun turi (Sesbania grandiflora). Agrinimal J 2 (2): 56-60. [Indonesian]

Kartadisastra. 1997. Penyediaan dan Pengolahan Pakan Ternak Ruminansia. Kanisius, Yogyakarta. [Indonesian]

Kartikasari S.N, Marshall AJ, Beehler BM. 2013. Ekologi Papua. Yayasan Obor. Indonesia. Jakarta. [Indonesian]

Kayadoe M, Koibur JF, Warmetan H. 2014a . Komposisi kimia dan komponen serat berbagai jenis pakan lokal yang berasal dari habitat asal kuskus dan penangkaran. Sains Peternakan 12 (1): 15-19. [Indonesian]

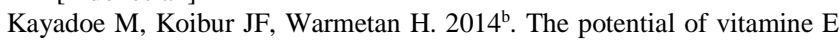
on several local plants papua as feed in different habitat cuscus. Vet Med J 30 (3): 174-177.

Kayadoe M, Sinaga S, Warmetan H, Koibur J. F, Yurmiati H, Rochana A, Tanuwiria UH. 2015. Evaluasi kebutuhan zat-zat makanan bagi kuskus bertotol (Spilocuscus maculatus) dalam penangkaran melalui penggunaan bahan pakan lokal. Prosid. Seminar Nasional Peternakan Berkelanjutan. 7-11 Nopember 2015. [Indonesian]

Parakkasi A. 1999. IlmuNutrisi dan MakananTernakRuminan. Universitas Indonesia Press. Jakarta. [Indonesian]

Pattiselanno F. and J.F. Koibur. Cuscus (Phalangeridae) hunting by Biak Etnic Group in surrounding North Biak Strict Nature Reserve, Papua. Hayati J Biosci 15 (3): 130-134.

Payne J, Francis C, Phillips M.K, Kartikasari SN. 2000. Panduan Lapangan Mamalia di Kalimantan, Sabah, Sarawak dan Brunei Darusalam Kinibalu: The Sabah Society and Wildlife Conservation Society Malaysia. [Indonesian]

Pond WG, Church DC, Pond KR. 1995. Basic Animal Nutrition and Feeding. 4th ed. John Wiley and Sons, New York.

Roosendaal B. 2014. Wildlife Nutrition and Feeding. https://spesfeed.com/2014/04/wildlife nutrition feeding/4

Saragih EW, Sadsoetoeboen MJ, Pattiselanno F. 2010. The Diet of Spotted Cuscus (Spilocuscus maculatus) in natural and captivity. Nusantara Biosci 2 (2): 78-83.

Sastrosupadi A. 1999. Rancangan Percobaan Praktis Bidang Pertanian. Kanisius. Yogyakarta. [Indonesian]

Sinaga W, Iskandar DA, Wirdateti E, Pamungkas J. 2010. Konsumsi Pakan Asal Hewan Pada Kukang (Nycticebus coucang) di Fasilitas Penangkaran. Pusat Studi Satwa Primata. Institut Pertanian Bogor. J Primatologi Indonesia 7 (2): 69-75. [Indonesian]

Sinery A, Manusawai J, Farida WR. 2014. Population and Carrying Capacity of Cuscus In Tourist Island of Ahe District of Nabire Province of Papua. Intl J Trop Nat Sci 1 (1): 19-23.

Sinery AS, Boer C, Farida WR.2013. Population dynamics of cuscus in tourist island of Ahe, District of Nabire, Papua. Biodiversitas 14: 95100.

Supriatna J, Wahyono E. H. 2000. Panduan Lapangan Primata Indonesia. Yayasan Obor Indonesia. Jakarta. [Indonesian]

Sutardi T. 1980. Landasan Ilmu Nutrisi. Jilid 1. Departemen Ilmu Makanan Ternak. Fakultas Peternakan. Institut Pertanian Bogor. Bogor. [Indonesian] 